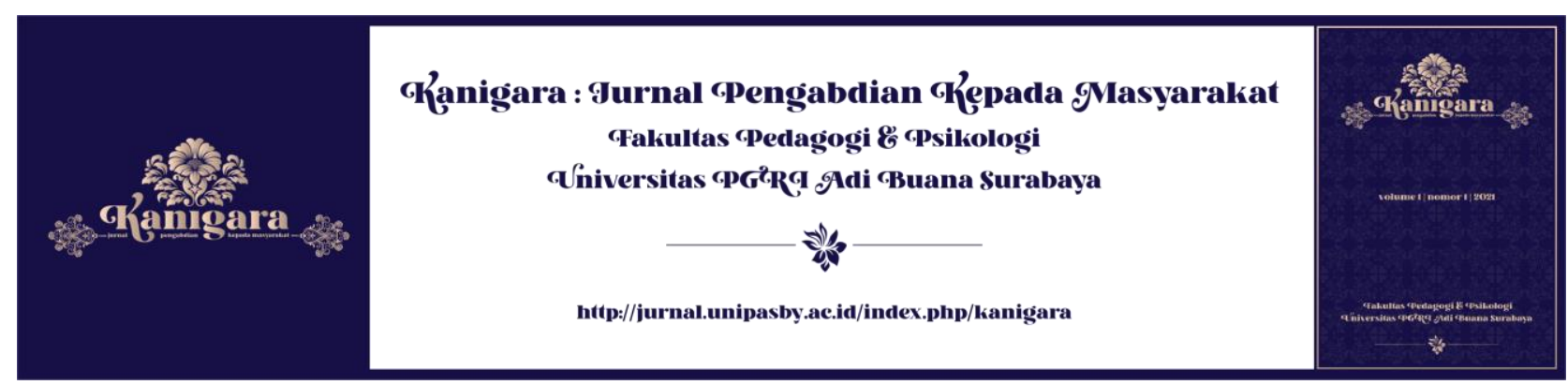

\title{
PENINGKATAN KOMPETENSI GURU SEKOLAH DASAR DALAM PENGEMBANGAN BAHAN AJAR DARING DI SDN MARGOREJO I KOTA SURABAYA PROVINSI JAWA TIMUR
}

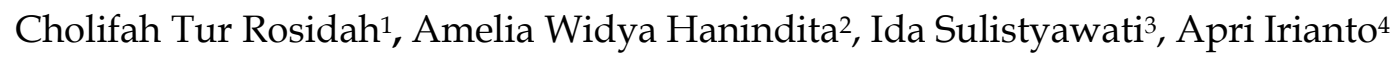 \\ 1,2,3, 4 Program Studi Pendidikan Guru Sekolah Dasar, Universitas PGRI Adi Buana, Surabaya, \\ Indonesia \\ *Email: ${ }^{1}$ cholifah@unipasby.ac.id
}

\begin{tabular}{l}
\hline Informasi Artikel \\
\hline Kata kunci: \\
Covid-19, \\
Kompetensi, Bahan Ajar \\
Daring.
\end{tabular}

Diterima: 16-01-2021

Disetujui: 23-01-2021

Dipubikasikan: 26-012021

\begin{abstract}
Abstrak
Kurang lebih enam bulan, berbagai elemen masyarakat di dunia dihantam wabah Covid-19, tanpa terkecuali dunia pendidikan. Saat ini pembelajaran daring memang tepat dan dibutuhkan untuk melanjutkan kegiatan belajar mengajar antara guru dengan murid. Itulah satu-satunya jalan terbaik agar kehidupan akademik terus memanjang. Namun, guru kesulitan dalam mengembangkan bahan ajar untuk pembelajaran daring, sehingga guru belum mampu melaksanakan pembelajaran daring secara maksimal. Hal ini karena pembelajaran daring merupakan pola pembelajaran yang baru sehingga guru belum menguasai dengan baik. Oleh sebab itu tim dosen PGSD Adi Buana Surabaya melakukan kegiatan Pengabdian Pada Masyarakat untuk mengenalkan dan memahamkan Pengembangan Bahan Ajar Daring. Metode pelaksanaan workshop adalah dengan presentasi secara daring, pemodelan dan simulasi disertai tugas. Hasilnya, guru-guru yang mendapatkan pelatihan dapat mengembangkan bahan ajar daring.

Abstract
Approximately six months, various elements of society in the world were hit by the
Covid-19 outbreak, without exception the world of education. Currently online
learning is appropriate and needed to continue teaching and learning activities
between teachers and students. That is the only best way for academic life to continue.
However, teachers have difficulty in developing teaching materials for online
learning, so that teachers have not been able to carry out online learning optimally.
This is because online learning is a new learning pattern so that teachers have not
mastered it well. Therefore, the PGSD Adi Buana Surabaya lecturer team carried out
Community Service activities to introduce and understand the Development of
Online Teaching Materials. The method of conducting the workshop is by online
presentation, modeling and simulation with assignments. As a result, teachers who
received training were able to develop online teaching materials.
\end{abstract}




\section{PENDAHULUAN}

Pembelajaran merupakan proses interaksi antara guru, siswa, dan sumber belajar untuk mencapai tujuan belajar yang diharapkan. Menurut Permendikbud Nomor 22 Tahun 2016, proses pembelajaran pada kurikulum 2013 menggunakan pendekatan saintifik atau pendekatan berbasis proses keilmuan. Oleh karena itu, guru mempunyai tanggung jawab untuk sedapat mungkin menciptakan situasi yang mendukung proses belajar mengajar sesuai Kurikulum 2013 (Fanny, 2019).

Kurang lebih enam bulan, berbagai elemen masyarakat di dunia dihantam wabah Covid19 atau yang populer di Indonesia disebut virus korona, tanpa terkecuali dunia pendidikan. Semua elemen, termasuk dunia pendidikan mau tidak mau harus menyesuaikan diri, agar tidak terombang-ambing di tengah badai virus yang telah memakan korban ratusan ribu ini. Dalam dunia pendidikan tersedia banyak pilihan media, dan masyarakat akademik tinggal memilih media yang tepat dan cocok digunakan. Saat ini pembelajaran daring memang tepat dan dibutuhkan untuk melanjutkan kegiatan belajar mengajar antara guru dengan murid atau dosen dengan mahasiswa (Gusty, dkk, 2020). Itulah satu-satunya jalan terbaik agar kehidupan akademik terus memanjang.

Pada Maret 2020 untuk pertama kalinya pemerintah mengumumkan 2 kasus positif covid19 di Indonesia. Wabah covid telah menjadi pandemi dan penyebarannya yang masif dan relatif cepat membuat berbagai elemen masyarakat mengubah strategi hidupnya. Dalam dunia pendidikan pemerintah menanggapi fenomena tersebut dengan cepat melalui Surat Edaran Mendikbud No. 3 Tahun 2020 tentang Pencegahan Covid-19 pada Satuan Pendidikan, dan No. 36962/MPK.A/HK/2020. Beberapa kebijakan tersebut diantaranya, 1) Pembelajaran daring pada anak sekolah; 2) Kuliah daring untuk mahasiswa; 3) Tidak ada Ujian Nasional 2020; 4) Pengunduran pelaksanaan UTBK SBMPTN 2020; dan 5) Pengkajian lebih lanjut untuk pelaksanaan SNMPTN. Beberapa kebijakan tersebut dilaksanakan sebagai antisipasi semakin meluasnya penyebaran covid-19.

Perubahan pola pembelajaran yang mulanya pembelajaran tatap muka menjadi pembelajaran online atau daring memaksa guru agar harus belajar dengan cepat. Salah satunya membuat Rencana Pelaksanaan Pembelajaran (RPP) daring. RPP merupakan pedoman guru dalam proses pembelajaran. Permendikbud No. 65 Tahun 2013 tentang Standar Proses dijelaskan RPP merupakan rencana kegiatan pembelajaran untuk satu pertemuan atau lebih. Bahan ajar merupakan salah satu bagian penting dalam proses pembelajaran. Sebagaimana Mulyasa (dalam Pentury, 2018) mengemukakan bahwa bahan ajar merupakan salah satu bagian dari sumber ajar yang dapat diartikan sesuatu yang mengandung pesan pembelajaran, baik yang bersifat khusus 
maupun yang bersifat umum yang dapat dimanfaatkan untuk kepentingan pembelajaran.

Dick, Carey, dan Carey (dalam Faishol, 2018) menambahkan bahwa instructional material contain the conten either written, mediated, or facilitated by an instructor that a student as use to achieve the objective also include information thet the learners will use to guide the progress. Berdasarkan ungkapan Dick, Carey, dan Carey dapat diketahui bahwa bahan ajar berisi konten yang perlu dipelajari oleh siswa baik berbentuk cetak atau yang difasilitasi oleh pengajar untuk mencapai tujuan tertentu.

Widodo dan Jasmadi dalam Magdalena, dkk (2020) menyatakan bahwa bahan ajar adalah seperangkat sarana atau alat pembelajaran yang berisikan materi pembelajaran, metode, batasanbatasan, dan cara mengevaluasi yang didesain secara sistematis dan menarik dalam rangka mencapai tujuan yang diharapkan, yaitu mencapai kompetensi dan subkompetensi dengan segala kompleksitasnya.

Beberapa definisi tersebut menggambarkan bahwa bahan ajar hendaknya dirancang dan ditulis sesuai dengan kaidah pembelajaran, yakni disesuaikan materi pembelajaran, disusun berdasarkan atas kebutuhan pembelajaran, terdapat bahan evaluasi, serta bahan ajar tersebut menarik untuk dipelajari oleh siswa. Berdasarkan informasi awal yang penulis peroleh, guru SD kesulitan dalam mengembangkan bahan ajar untuk pembelajaran daring, sehingga guru belum mampu melaksanakan pembelajaran daring secara maksimal. Hal ini dikarenakan pembelajaran daring merupakan pola pembelajaran yang baru sehingga guru belum menguasai dengan baik, khususnya dalam merancang aktivitas pembelajarannya.

Lokasi pengabdian berada di SDN Margorejo I Surabaya Provinsi Jawa Timur. Berdasarkan hasil wawancara dengan beberapa guru SD di sekolah tersebut, menyatakan bahwa pelatihan pengembangan bahan ajar daring belum dilakukan. Itulah sebabnya kegiatan pelatihan pengembangan bahan ajar, khususnya bahan ajar daring penting dilakukan mengingat untuk saat ini hal tersebut sebagai kebutuhan yang mendesak.

Kegiatan PPM ini akan dilaksanakan pada guru SD di SDN Margorejo I Surabaya Provinsi Jawa Timur. Guru yang terlibat, hasil akhirnya akan diminta untuk membuat bahan ajar daring. Melalui kegiatan ini, diharapkan dapat meningkatkan pemahaman guru tentang pengembangan bahan ajar daring serta meningkatkan motivasi guru SDN Margorejo I Surabaya untuk melakukan inovasi-inovasi dalam pembelajaran baik tatap muka maupun daring sehingga siswa juga bersemangat dalam mengikuti proses pembelajaran.

Berdasarkan hal tersebut di atas, maka tim dosen PGSD Adi Buana Surabaya yang berpengalaman untuk melakukan suatu kegiatan Pengabdian Pada Masyarakat dengan judul “Peningkatan Kompetensi Guru Sekolah Dasar Dalam Pengembangan Bahan Ajar Daring di SDN 
Margorejo I Kota Surabaya Provinsi Jawa Timur". Tujuannya, yaitu mengenalkan dan memahamkan Pengembangan Bahan Ajar Daring. Berakhirnya pelaksanaan program PPM Prodi PGSD Fakultas Pedagogi dan Psikologi Universitas PGRI Adi Buana Surabaya diharapkan mampu menyelesaikan permasalahan guru dalam menyusun dan mengembangkan Bahan Ajar Daring.

\section{METODE PELAKSANAAN}

Metode pelaksanaan workshop adalah dengan presentasi secara daring, pemodelan dan simulasi disertai tugas. Presentasi merupakan sebuah metode penyampaian materi secara sistematis oleh presentator tanpa menggunakan banyak media. Bahan presentasi adalah tentang pengembangan bahan ajar daring. Kemudian instruktur berdiskusi dengan guruguru, dengan memberikan contoh-contoh bahan ajar daring yang telah selesai dikembangkan sebelumnya. Metode pemodelan merupakan metode memberikan contoh-contoh kepada peserta sehingga mereka dapat menirunya. Serta tim meminta guru untuk mengembangan bahan ajar daring sesuai dengan rencana pembelajaran di kelas guru masing-masing. Metode penugasan adalah metode memberikan tugas kepada peserta agar dapat dikerjakan diluar waktu workshop. Instruktur menilai hasil kerja guru. Pada tahap akhir, guru diberikan angket kepuasan untuk menghitung feedback guru terhadap pelaksanaan workshop.

Pelaksanaan kegiatan Pengabdian Pada Masyarakat (PPM) dilaksanakan secara online melalui aplikasi zoom meeting. Kegiatan tersebut dilaksanakan pada bulan September 2020. Kegiatan Pengabdian Pada Masyarakat ini dilaksanakan dalam bentuk pelatihan dan workshop dengan diawali pemaparan materi, diskusi, dan workshop dengan pendampingan dosen saat kerja kelompok. Berikut materi pembelajaran, pelatihan dan pelaksana dari kegiatan Pengabdian Pada Masyarakat yang dilakukan oleh tim PGSD Universitas PGRI Adi Buana Surabaya.

\begin{tabular}{|c|c|c|}
\hline No & Materi & Pelaksana \\
\hline 1. & Hakikat Bahan Ajar & 1. Cholifah Tur Rosidah, S.Pd., M.Pd. \\
\hline 2. & $\begin{array}{l}\text { Perbedaan Bahan Ajar Luring dan } \\
\text { Daring }\end{array}$ & Amelia Widya Hanindita, S.Pd., M.Pd. \\
\hline 3. & $\begin{array}{l}\text { Langkah-Langkah } \quad \text { Pengembangan } \\
\text { Bahan Ajar Daring. }\end{array}$ & $\begin{array}{l}\text { 1. Ida Sulistyawati, S.H., M.Pd. } \\
\text { 2. Apri Irianto, SH., M.Pd. }\end{array}$ \\
\hline
\end{tabular}

\section{HASIL DAN PEMBAHASAN}

Kelompok sasaran dalam kegiatan Pengabdian Kepada Masyarakat (PPM) ini adalah guru di SDN Margorejo I Kota Surabaya. Kondisi profil kelompok sasaran memberikan 
gambaran bahwa potensi guru SD di sekolah tersebut telah sarjana dan mayoritas sudah PNS, sehingga memungkinkan lebih mudah untuk ditingkatkan dan diberdayakan menjadi lebih potensial dan profesional. Namun kondisi saat ini masih ditemukan beberapa guru yang belum mampu menyusun bahan ajar daring dengan baik. Sementara itu bahan ajar daring saat ini sangat dibutuhkan dalam proses pembelajaran di masa pandemi covid-19 yang mengharuskan siswa belajar dari rumah. Selain itu kemampuan pengembangan bahan ajar daring juga dapat menjadi sarana guru menjadi pendidik yang profesional. Untuk itu maka kami menganggap penting bahwa pelatihan Pengembangan bahan ajar daring ini perlu dilakukan.

Sementara itu melihat kondisi kelompok sasaran masih belum pernah mendapatkan pelatihan tersebut dari Dosen PGSD Unipa Surabaya. Untuk itu tim dosen Program Studi PGSD Universitas PGRI Adi Buana Surabaya menganggap bahwa Pelatihan Peningkatan Kompetensi Guru Sekolah Dasar Dalam Pengembangan Bahan Ajar Daring di SDN Margorejo I Kota Surabaya Provinsi Jawa Timur penting dilaksanakan.

\section{A. Pertemuan Pertama}

Pelaksanaan kegiatan Pengabdian Pada Masyarakat (PPM) ini dilaksanakan secara daring melalui aplikasi zoom cloud, karena pandemi covid-19 masih belum memungkinkan melaksanakan pertemuan secara langsung (luring). Secara keseluruhan, kegiatan tersebut dilaksanakan pada September 2020. Kegiatan Pengabdian Pada Masyarakat ini dilaksanakan dalam bentuk workshop dengan diawali pemaparan materi, diskusi, dan workshop dengan pendampingan dosen saat kerja kelompok. Pelaksanaan pertama dilaksanakan pada tanggal 4 September 2020 dan seluruh pemateri dan beberapa mahasiswa yang terlibat hadir dalam workshop. Workshop dibagi dalam dua sesi untuk tiga materi. Sesi pertama materi pertama dimulai pukul 08.00 sampai dengan pukul 09.30. Sesi dua materi kedua dimulai pukul 09.30 sampai dengan pukul 12.00. Setelah itu peserta dipersilakan untuk ishoma yang kemudian dilanjutkan sesi dua materi ketiga pada pukul 13.00 sampai dengan pukul 15.30. Kegiatan PPM tersebut dirinci sebagai berikut.

\section{Hakikat Bahan Ajar}

Materi Hakikat Bahan Ajar disampaikan Cholifah Tur Rosidah, S.Pd., M.Pd. Ruang lingkup materi berkaitan pengertian, karakter, prinsip, tujuan, dan manfaat bahan ajar, serta sedikit menyinggung mengenai bahan ajar daring. Materi disampaikan melalui power point dan 100\% berupa teori untuk pemahaman. Cholifah Tur Rosidah, S.Pd., M.Pd., mempresentasikan mengenai Hakikat Bahan Ajar selama enam puluh menit (08.00 09.00). 
Sisa waktu tiga puluh menit digunakan untuk tanya jawab, serta interaksi antara satu peserta dengan peserta lainnya. Peserta yang mengikuti workshop dapat dikatakan aktif melakukan diskusi. Pada materi pertama ini ada delapan pertanyaan yang dibagi dalam tiga termin. Sesi pertama ini diakhiri pukul 09.30.

\section{Perbedaan Bahan Ajar Luring dan Daring}

Materi Perbedaan Bahan Ajar Luring dan Daring disampaikan oleh Amelia Widya Hanindita, S.Pd., M.Pd. Materi yang disampaikan mengacu pada buku guru dan buku siswa yang berdasar kurikulum 2013 dan pembelajaran terpadu di sekolah dasar, serta kurikulum merdeka belajar dan RPP daring yang telah disusun pada kegiatan sebelumnya. Pada kegiatan ini materi yang disampaikan berkaitan dengan sintak pembelajaran, sistem pembelajaran, kelebihan dan kelemahan bahan ajar saat ini. Materi tentang Bahan Ajar Luring dan Daring disampaikan selama enam puluh menit (09.30 10.30). Pukul 10.30 - 11.00 digunakan untuk tanya jawab dan diskusi. Tanya jawab dibagi menjadi dua termin. Termin pertama lima belas menit dan termin dua lima belas menit. Termin pertama ada dua penanya, dan termin kedua ada tiga penanya. Pukul 11.00 - 12.00 peserta PPM bertugas membuat kerangka bahan ajar. Sesi dua ini berakhir pukul 12.00 .

\section{Langkah-Langkah Pengembangan Bahan Ajar Daring}

Materi Langkah-Langkah Pengembangan Bahan Ajar Daring disampaikan oleh Ida Sulistyawati, S.H., M.Pd., dan Apri Irianto, S.H., M.Pd. Materi yang disampaikan, di antaranya (1) Mengidentifikasi faktor yang ada pada kompetensi dasar dan standar kompetensi; (2) Menentukan jenis bahan ajar yang cocok untuk kompetensi yang harus diraih; (3) Menentukan referensi bahan ajar. Materi Mengidentifikasi faktor yang ada pada kompetensi dasar dan Menentukan jenis bahan ajar yang cocok untuk kompetensi yang harus diraih disampaikan oleh Ida Sulistyawati, S.H., M.Pd. selama empat puluh lima menit (13.00 - 13.45). Materi Menentukan referensi bahan ajar disampaikan selama tiga puluh menit (13.45 - 14.15) oleh Apri Irianto, S.H., M.Pd. Pukul 14.15 - 15.15 digunakan untuk diskusi dan tanya jawab. Pada sesi ini, tanya jawab dilakukan dalam tiga termin. Peserta yang berpartisipasi bertanya sepuluh orang dan dijawab bergantian oleh dua pemateri. Pukul 15.30 salah satu pemateri (Ida Sulistyawati, S.H., M.Pd.) melakukan simpulan umum, dan kemudian memberikan tugas peserta untuk menyusun bahan ajar daring sesuai kerangka yang telah dibuat pada sesi kedua. Bahan ajar daring yang telah disusun nantinya akan didiskusikan pada pertemuan berikutnya. Diskusi diakhiri pukul 15.30.

\section{B. Pertemuan Kedua}

Pelaksanaan kegiatan Pengabdian Pada Masyarakat (PPM) pertemuan kedua ini tetap dilaksanakan secara daring melalui aplikasi zoom cloud. Pelaksanaan kedua dilaksanakan 
pada tanggal 5 September 2020 dan seluruh pemateri dan beberapa mahasiswa yang terlibat hadir dalam workshop. Workshop hanya dilaksanakan satu sesi saja, karena pada pertemuan ini peserta bertugas mempresentasikan hasil kerjanya berupa bahan ajar daring. Pertemuan daring ini dimulai pukul 08.00 sampai dengan pukul 15.00. Pada pertemuan kedua ini kegiatan bersifat praktis. Artinya, peserta melakukan unjuk kerja dengan mempresentasikan bahan ajar daring yang telah dibuat. Pemateri bertindak sebagai tutor workshop atau teman diskusi.

\section{Presentasi Bahan Ajar Daring}

Pemateri yang bertugas sebagai tutor workshop, yaitu Ida Sulistyawati, S.H., M.Pd., dan Apri Irianto, S.H., M.Pd. Pada pukul 08.00 - 10.00 peserta melakukan presentasi mengenai bahan ajar daring yang telah dibuat. Pada pertemuan ini antar peserta saling memberikan masukan dan kritik terhadap hasil kerja (bahan ajar daring) rekan-rekannya. Bahan ajar daring yang telah disusun memiliki perbedaan sigifikan satu sama lain. Beberapa peserta ada yang tidak setuju dengan bahan ajar yang disusun rekannya, bekitu juga sebaliknya. Diskusi dan tanya jawab berjalan alot, karena semua peserta mempunyai argumentasi yang berbeda mengenai bahan ajar daring. Pada pukul 10.00 diskusi selesai dan kemudian dilanjutkan evaluasi dari dosen. Evaluasi berjalan dengan baik. Ida Sulistyawati, S.H., M.Pd., menyampaikan, bahwa dalam pembuatan bahan ajar, dibutuhkan langkah-langkah konkret yang tidak boleh sembarangan. Langkah-langkah penyusunan bahan ajar harus berdasarkan dengan kurikulum yang berlaku. Supaya memudahkan untuk membuat bahan ajar, guru harus memahami prinsip-prinsip pengembangan bahan ajar. Evaluasi berakhir pukul 12.00. Peserta dipersilakan untuk ishoma terlebih dulu dan kemudian dilanjutkan pendalaman materi bahan ajar daring, mengingat bahan ajar daring yang telah dibuat belum memenuhi standar yang ditentukan.

\section{Pendalaman Pengembangan Bahan Ajar Daring}

Pada pertemuan ini peserta mendapatkan materi tentang pendalaman pengembangan bahan ajar daring. Pada pertemuan ini, Apri Irianto, S.H., M.Pd., bertugas sebagai pemateri, dan sekaligus menjadi pemandu. Materi disampaikan selama enam puluh menit (13.00 - 14.00). Apri Irianto, S.H., M.Pd., menyampaikan materi yang meliputi (1) Prinsip pengembangan bahan ajar; dan (2) Teknik Penyusunan Bahan Ajar Daring yang Interaktif. Setelah itu pada pukul 14.00 - 15.00 peserta secara mandiri diberi tugas menyusun bahan ajar daring. Penyusunan bahan ajar daring pada pertemuan ini untuk memperbaiki kesalahan pada pertemuan sebelumnya. Pemateri workshop menjadi pemandu sesi tugas. Sisa waktu digunakan untuk tanya jawab dan hanya ada dua 
penanya. Waktu yang tidak memungkinkan akhirnya tim PPM meminta peserta menyelesaikan bahan ajar daring di rumah dan dikumpulkan melalui email: pgsd.unipasby.ac.id. untuk diskusi lebih lanjut peserta dapat bertanya melalui Grup WhatsApp. Berakhirnya diskusi tentang materi bahan ajar daring ini, maka berakhir pula rangkaian kegiatan PPM yang berjudul “Peningkatan Kompetensi Guru Sekolah Dasar Dalam Pengembangan Bahan Ajar Daring di SDN Margorejo I Kota Surabaya Provinsi Jawa Timur".

\section{KESIMPULAN}

Kurang lebih enam bulan, berbagai elemen masyarakat di dunia dihantam wabah Covid19 atau yang populer di Indonesia disebut virus korona, tanpa terkecuali dunia pendidikan. Semua elemen, termasuk dunia pendidikan mau tidak mau harus menyesuaikan diri, agar tidak terombang-ambing di tengah badai virus yang telah memakan korban ratusan ribu ini. Dalam dunia pendidikan tersedia banyak pilihan media, dan masyarakat akademik tinggal memilih media yang tepat dan cocok digunakan. Saat ini pembelajaran daring memang tepat dan dibutuhkan untuk melanjutkan kegiatan belajar mengajar antara guru dengan murid atau dosen dengan mahasiswa. Implikasi dari pembelajaran daring tersebut, guru harus dapat membuat dan atau menyusun bahan ajar daring pula agar pembelajaran lebih mudah dilaksanakan. Itulah satusatunya jalan terbaik agar kehidupan akademik terus memanjang.

Berdasarkan hal tersebut, tim dosen Program Studi PGSD Universitas PGRI Adi Buana Surabaya melaksanakan PPM mengenalkan dan memahamkan Pengembangan Bahan Ajar Daring. PPM dilaksanakan selama dua hari (dua pertemuan). Materi yang disampaikan pada pertemuan pertama meliputi (1) Hakikat Bahan Ajar; (2) Perbedaan Bahan Ajar Luring, dan Bahan Ajar Daring; (3) Langkah-Langkah Pengembangan Bahan Ajar Daring. Pada pertemuan kedua peserta mempresentasikan hasil kerjanya (bahan ajar daring). Kegiatan pada pertemuan dua meliputi (1) Presentasi Bahan Ajar Daring; (2) Pendalaman Pengembangan Bahan Ajar Daring.

Berakhirnya pelaksanaan program PPM Program Studi PGSD Universitas PGRI Adi Buana Surabaya yang berjudul Peningkatan Kompetensi Guru Sekolah Dasar Dalam Pengembangan Bahan Ajar Daring di SDN Margorejo I Kota Surabaya Provinsi Jawa Timur ini dapat menyelesaikan permasalahan guru dalam menyusun dan mengembangkan bahan ajar daring, serta mengelaborasi pembelajaran berdasarkan kurikulum merdeka belajar. 


\section{DAFTAR PUSTAKA}

Faishol, R. (2018). Pengembangan Paket Pembelajaran Ilmu Pengetahuan Sosial (IPS) Kelas IV Menggunakan Model Dick, Carey \& Carey di SD Negeri 2 Tamanagung. Tarbiyatuna: Kajian Pendidikan Islam, 2(2), 31-49.

Fanny, A. M. (2019, March). Analysis Of Pedagogical Skills And Readiness Of Elementary School Teachers In Support Of The Implementation Of The 2013 Curriculum. In International Conference on Bussiness Law and Pedagogy (Vol. 1, No. 1, pp. 59-63).

Gusty, S., Nurmiati, N., Muliana, M., Sulaiman, O. K., Ginantra, N. L. W. S. R., Manuhutu, M. A., ... \& Warella, S. Y. (2020). Belajar Mandiri: Pembelajaran Daring di Tengah Pandemi Covid-19. Yayasan Kita Menulis.

Magdalena, I., Rahmanda, F. P., Armianti, I. J., \& Nabilah, S. (2020). Pengaruh Penggunaan Bahan Ajar Online terhadap Prestasi Siswa di SDN Sukamanah 01. BINTANG, 2(3), 431-445.

Pentury, H. J. (2018). Pengembangan literasi guru PAUD melalui bahan ajar membaca, menulis dan berhitung di Kecamatan Limo dan Cinere. DIKEMAS (Jurnal Pengabdian Kepada Masyarakat), 1(1). 